\title{
Once-a-day pediatric HAART with DDI+3TC+EFV in Burkina Faso. A phase II trial (ANRS I 2 I 03 trial)
} Philippe Msellati*1, Boubacar Nacro², Emmanuelle Zoure2, Hervé Hien ${ }^{3}$, Hassane Tamboura ${ }^{2}$, François Rouet ${ }^{3}$, Serge Diagbouga ${ }^{3}$, Adama Ouiminga ${ }^{3}$, Ali Drabo ${ }^{3}$, Souleymane Yaméogo ${ }^{3}$, Hélène Peyrière ${ }^{4}$, Olivier Mathieu ${ }^{4}$, Joëlle Nicolas ${ }^{4}$ and Philippe Van de Perre ${ }^{4}$

Address: ${ }^{1}$ UMR 145 IRD, Bobo-Dioulasso, Burkina Faso, ${ }^{2}$ Department of Pediatrics, CHU de Bobo-Dioulasso, Burkina Faso, ${ }^{3}$ Centre Muraz, BoboDioulasso, Burkina Faso and ${ }^{4}$ Laboratory of Medical Pharmacology and Laboratory of Virology, Montpellier University Hospital, Montpellier, France

* Corresponding author

from Fourth Dominique Dormont International Conference. Host-Pathogen Interactions in Chronic Infections

Paris, France. 13-15 December 2007

Published: 9 April 2008

Retrovirology 2008, 5(Suppl I):O26 doi:10.1186/1742-4690-5-SI-O26

This abstract is available from: http://www.retrovirology.com/content/5/SI/O26

(c) 2008 Msellati et al.; licensee BioMed Central Ltd.

\section{Background}

Simplification of the administration of HAART in children should improve compliance and efficacy of these treatments. Combination of 3TC $+\mathrm{DDI}+\mathrm{EFV}$ in a single daily oral administration is one option. However, pharmacokinetics, tolerance and efficacy of such once-a-day HAART have not been assessed in children. The ANRS 12103 trial is a phase II on pharmacokinetics, tolerance and compliance of a once-a-day pediatric $\mathrm{DDI}+3 \mathrm{TC}+\mathrm{EFV}$ in Burkina Faso.

\section{Material and methods}

ANRS 12103 is an ongoing Open Phase II Trial with a 12 months follow up. 50 HIV-1 infected children eligible for HAART had to be included. Inclusion criteria were: weight $\geq 10 \mathrm{~kg}$ and aged 30 months to 15 years, naive of ARV treatment and eligible for HAART. Children received efavirenz + 3TC $(8 \mathrm{mg} / \mathrm{kg})+$ DDI $(240 \mathrm{mg} / \mathrm{m} 2)$. Clinical examination was performed weekly until M3, then monthly. Pharmacokinetics (plasma Cmin and Cmax) was done at day 15. Quaterly RNA HIV-1, CD4 counts, haematology and biochemistry are performed.

\section{Results}

Enrolment was from February to November 2006 and 98 HIV-infected children have been screened for eligibility criteria: 45 were excluded, one died before inclusion and 52 were included. Among included children there was 21 girls and 31 boys, mean age was 6.8 years, Zscore Weight for Age (W/A) and Height for Age (H/A) were respectively

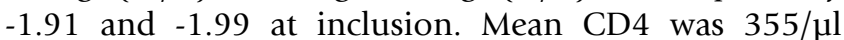
(mean CD4 percentage 9\%), and median HIV-1 RNA 5.50 $\log _{10} \mathrm{cp} / \mathrm{ml}$. Among the 52 expected samples for minimum concentration of efavirenz, 50 were obtained. Thirty children were in the expected ranges (60.1\%), 11 (22\%) below therapeutic levels and $9(18 \%)$ above therapeutic levels. Maximum concentrations were in the expected ranges in $23 / 49$ children $(47 \%)$, below therapeutic levels in $3 / 49$ children (6\%) and over in 23/49 children. Dosages of $3 \mathrm{TC}$ and DDI are ongoing.

At 9 months of follow-up, two children had died, Zscore W/A and H/A were respectively -1.37 and -1.62 , and mean CD4 was 893/ $\mu$ l (mean CD4 percentage 20\%). HIV-1 RNA was below detectable level (300 copies/ml) in 39 children $(76 \%)$ and below 1000 copies/ml in two children (4\%).Two HAART adverse effect occurred. One cuta- 
neous eruption with a temporary stop and successful reintroduction and one increase in liver enzymes.

\section{Conclusion}

Preliminary data of this phase II trial suggest that once-aday DDI+3TC+EFV in children provides satisfactory plasma concentration for $\mathrm{EFV}$, and is associated with virological success and immune restoration. At 9-month follow up, it is effective and well tolerated.

Publish with Bio Med Central and every scientist can read your work free of charge

"BioMed Central will be the most significant development for disseminating the results of biomedical research in our lifetime. " Sir Paul Nurse, Cancer Research UK

Your research papers will be:

- available free of charge to the entire biomedical community

- peer reviewed and published immediately upon acceptance

- cited in PubMed and archived on PubMed Central

- yours - you keep the copyright

Submit your manuscript here:

http://www.biomedcentral.com/info/publishing_adv.asp 